\title{
PENGEMBANGAN BUKU PANDUAN PROGRAM PEMBELAJARAN KETERAMPILAN SOSIAL BAGI GURU TAMAN KANAK-KANAK
}

\author{
Rita Eka Izzaty, Farida Agus Setiawati, dan Yulia Ayriza \\ Universitas Negeri Yogyakarta \\ Email: rita_ekaizzaty@uny.ac.id
}

\begin{abstract}
Abstrak
Pembelajaran yang mengembangkan kemampuan sosial terutama keterampilan sosial belum dilakukan dengan perencanaan yang baik di Taman Kanak-kanak. Hal ini dapat mengakibatkan tujuan pembelajaran di Taman Kanak-kanak menjadi kurang terprogram. Penelitian ini merupakan penelitian pengembangan dengan menggunakan model pengembangan dari Dick \& Carry yang bertujuan untuk mengembangkan panduan program pembelajaran yang yang mengembangkan keterampilan sosial anak Taman Kanak-kanak. Subyek penelitian adalah para pendidik di Taman Kanak-kanak yang berasal di Kabupaten Sleman, Bantul, Gunung Kidul, Kulon Progo, dan Kotamadya Yogyakarta. Setiap kabupaten diwakili oleh 15 pendidik. Metode pengumpulan data menggunakan pemberian angket dan Focus Group Discussion (FGD) pada pendidik dan observasi pada anak menggunakan pedoman observasi berupa cheklist. Data yang sudah terkumpul selanjutnya dianalisis dengan diskriptif kualitatif dan kuantitatif. Data-data hasil dari FGD dan angket dianalisis secara deskriptif kualitatif dan kuantitatif, sedangkan data dari observasi melalui cheklist dianalisis dengan teknik statistik uji t parametrik untuk mengetahui peningkatan keterampilan sosial anak TK setelah mendapatkan program pembelajaran menggunakan buku panduan yang menstimulasi keterampilan sosial. Hasil dari penelitian dengan terciptanya pedoman pembelajaran keterampilan sosial yang telah melalui evaluasi awal atau uji ahli dan ujicoba di lapangan. Hasil validasi ahli menunjukkan pedoman pembelajaran keterampilan sosial layak untuk digunakan setelah melengkapi daftar isi, evaluasi pembelajaran dan memperbaiki kesalahan tata tulis. Demikian pula hasil masukan dari pendidik TK menunjukkan bahwa secara keseluruhan pedoman pembelajaran keterampilan sosial yang dibuat peneliti menunjukkan cukup baik dari aspek pembelajaran, tampilan. Hasil implementasi di TK menunjukkan bahwa panduan pembelajaran keterampilan sosial dapat meningkatkan rata-rata skor keterampilan sosial anak TK pada ketiga aspek keterampilan sosial dengan signifikan, yaitu pada pada aspek empati, afiliasi dan resolusi konflik, dan pengembangan kebiasaan positif.
\end{abstract}

Kata Kunci: buku panduan, keterampilan sosial, Taman Kanak-kanak

\section{DEVELOPMENT OF GUIDE BOOK OF SOCIAL SKILL LEARNING PROGRAM FOR KINDERGARTEN TEACHER}

\begin{abstract}
The learning program which stimulates the social skill to kindergarten children has not been done with good planning. It makes the purpose of social skill learning not programmed well. This research aims at developing a guidebook of social skill learning program to stimulate learning social skills for teachers in kindergarten. It is the research and developmental research, which employed developmental model of Dick \& Carry. The subjects are kindergarten teachers from Sleman, Bantul, Gunung Kidul, Kulon Progo, and Kotamadya Yogyakarta. Every district was represented by 15 teachers. The data were collected by using Focus Group Discussion (FGD) and questionnaire to the teachers, and guideline of observation checklist to observe the children. The distributed data from teachers were analyzed using qualitative and quantitative descriptive. The data from children were
\end{abstract}


analyzed by using $t$ test of statistic parametric to analysis the increase of social skills after implementing the learning program by using the guidebook of social skill. The result of research creates the guidebook of social skill program that validated by the experts, evaluated by the teachers and implemented to the children. The experts' judgment indicates that the book can be used by teachers after completing contents of the book, as well as the evaluation learning, and revising some written error. The review from the teachers indicates that the guidebook is reasonably used in kindergarten after revising many scenarios of learning. After this process is completed, the guidebook is implemented by 31 teachers in their class. The result of implementation shows that this book can be implemented and significantly increased the student's social skill especially in the aspects of empathy, affiliation, resolution conflict, and positive habits.

Keywords: guide book, social skills, kindergarten

\section{PENDAHULUAN}

Faktor pendidikan awal sangat berperan dalam membentuk kesan positif anak terhadap sekolah. Taman Kanakkanak sebagai salah satu jenjang pendidikan prasekolah memiliki arti penting sebagai jembatan antara keluarga dan sekolah formal. TK merupakan area penting tempat anak-anak belajar mengembangkan potensi diri dan mengembangkan kemandiriannya. Selain itu, di TK anak dapat memperoleh pengalaman yang lain yaitu tunduk pada otoritas selain orangtuanya. Anak mendapat bimbingan dari pendidik dengan gaya dan pendekatan yang berbeda dengan yang selama ini diperoleh dari orangtuanya. Pengalaman inilah yang membuat anak menjadi lebih memahami perlunya melihat sebuah persoalan dari sudut pandang orang lain (Izzaty, 2004:34). Hasil penelitian Izzaty (2005:10) pada anak usia TK menunjukkan bahwa prediktor yang terbukti berkorelasi secara signifikan, berhubungan secara langsung, dan memberikan sumbangan sebesar 21,45 $\%$ terhadap tingkah laku bermasalah anak, yaitu kurangnya kemampuan pendidik dalam menstimulasi perkembangan emosi dan sosial anak.

Dalam kurikulum untuk anak prasekolah, Curtis (1988:65) menyatakan bahwa keterampilan sosial merupakan strategi yang digunakan ketika orang berusaha memulai ataupun mempertahankan suatu interaksi sosial. Kelly (Ramdhani, 1991:34) mengatakan bahwa keterampilan sosial adalah keterampilan yang diperoleh individu melalui proses belajar yang digunakan dalam berhubungan dengan lingkungannya dengan cara baik dan tepat. Hal ini bertujuan untuk mendapatkan pengukuh dari hubungan interpersonal yang dilakukan dan menolak hadirnya suatu keadaan yang tidak menyenangkan. Sementara itu ahli lain, menurut Morgan (Cartledge \& Milburn, 1995:45) adalah kemampuan untuk menyatakan dan berinteraksi secara positif dengan orang lain. Keterampilan sosial juga diartikan sebagai kemampuan untuk berperilaku sesuai dengan keinginan lingkungan sosial dan menghindari perilaku negatif dari berbagai konteks sosial. Anak-anak yang memiliki kompetensi sosial adalah anakanak yang memiliki perilaku-perilaku yang baik dan responsif terhadap situasi sosial (Stormshak \& Welsch, 2005:111). Rogers dan Ross (Brewer, 2007:49) menggambarkan keterampilan sosial sebagai kemampuan untuk menilai apa yang sedang terjadi dalam suatu situasi sosial, keterampilan untuk memahami dan menginterpretasikan secara tepat tindakan dan kebutuhan anak-anak dalam kelompok pada saat mereka bermain; dan keterampilan untuk membayangkan beberapa kemungkinan alternatif tindakan dan memilih salah satu yang paling memadai.

Dari beberapa batasan yang dikemukakan ini, dapat disimpulkan bahwa keterampilan sosial adalah 
keterampilan atau strategi yang digunakan untuk memulai ataupun mempertahankan suatu hubungan yang positif dalam interaksi sosial, yang diperoleh melalui proses belajar dan bertujuan untuk mendapatkan hadiah atau penguat dalam hubungan interpersonal yang dilakukan.

Keterampilan sosial berhubungan dengan pola pemecahan masalah, hal ini berdasarkan survey yang dilakukan Izzaty (2008) terhadap 35 Taman kanak-kanak di Yogyakarta berkenaan dengan pemecahan masalah sosial anak, bahwa strategi penyelesaian permasalahan yang jumlahnya paling banyak dilakukan anakanak pada saat berinteraksi adalah strategi yang cenderung negatif atau bersifat agresi, seperti memukul, menendang, menjambak, dan mencubit. Hasil survey ini menguatkan penelitian Mayeux \& Cillessen (2003:164) yang meneliti anak usia TK dan kelas 1 Sekolah Dasar memperlihatkan adanya kestabilan pola-pola yang diberikan anak, baik yang bersifat antisosial dan prososial seiring dengan perkembangan usia. Asendorpf, Denissen, dan Aken (2008:999) juga menguatkan penelitian sebelumnya dengan hasil penelitian longitudinal selama 19 tahun. Hasil penelitiannya menunjukkan bahwa anakanak yang memiliki cara agresif dalam memecahkan masalahnya, ternyata pada usia 23 tahun perilaku ini masih terlihat kuat. Sebaliknya, anak-anak yang cenderung malu-malu atau inhibisi (inhibited) juga terlihat kuat pada usia 23 tahun. Dari sini dapat dikatakan bahwa respon ataupun cara yang digunakan individu pada usia awal akan cenderung tetap muncul pada usia dewasa.

Pola penyelesaian permasalahan sosial ini bukanlah terbentuk secara tibatiba, namun merupakan imitasi dan pembiasaan dari lingkungan terdekat anak, sehingga anak tidak memahami konteks sosial yang dihadapinya dan tidak terbiasa menggunakan cara-cara yang diterima secara sosial. Hal yang perlu diingat adalah dalam kehidupan manusia, tidak mungkin bersih dari perbedaan yang ada baik antar individu maupun antar kelompok sosial.
Dari sejak dini, seorang anak harus berani dan mampu menghadapi perbedaan dalam kehidupan sosial ini. Modal anak untuk mengatasi perbedaan ini adalah keterampilan sosial. Keterampilan sosial sebagai bagian dari life skill merupakan modal dasar utuk berinteraksi. Kemampuan untuk bekerjasama dengan penuh pengertian, rasa empati, dan kemampuan berkomunikasi dua arah merupakan bagian dari keterampilan sosial sangat dibutuhkan oleh seseorang dalam menjalin hubungan yang harmonis. Oleh karena itu, sejak usia dini, anak dituntut untuk mempunyai keterampialn sosial agar dapat berdampingan dengan orang lain dan lingkungan sekitar. Dengan adanya keterampilan sosial anak sejak usia dini, maka anak dapat belajar untuk menghargai perbedaan antar individu sehingga tidak memicu situasi yang tidak diinginkan.

Beranjak dari penjelasan dan fenomena di atas, hubungan yang kuat antara penanaman keterampilan sosial dengan lembaga pendidikan sejak dini perlu dilakukan bersama. Hal ini sejalan dengan pendapat Shure dan Spivak (Lawhon \& Lawhon, 2000:56) bahwa keterampilan sosial pada anak-anak dapat dibentuk melalui kurikulum di lembaga pendidikan usia dini. Peningkatan dalam perilaku dapat ditingkatkan melalui aktivitas dari program-program pembelajaran.

Penelitian yang dilakukan oleh Ayriza, Izzaty, \& Setiawati bersama Pusdi PAUD UNY selama kurun waktu tiga tahun, yakni tahun 2004-2006, menemukan bahwa pemahaman pendidik TK dalam kajian keterampilan sosial sangat minim dan beberapa bentuk program yang ada dilakukan dengan tidak sadar atau tidak terprogram dengan jelas. Kemudian, penelitian dilanjutkan dengan membuat modul yang terdiri dari 3 sub. Ketiga sub modul tersebut terdiri dari empati, afiliasi dan resolusi konflik, serta pengembangan kebiasaan positif. Tahun 2005, modul tersebut divalidasi. Selanjutnya pada tahun 2006, modul disosialisasikan. Namun mengingat latar 
belakang pendidikan pendidik TK yang berasal tidak dari jurusan yang terkait dengan pendidikan anak usia dini, beberapa pendidik, ada yang kesulitan untuk pengembangan program kegiatan belajar yang sudah dicontohkan di dalam modul. Oleh karena itu, diperlukan buku pegangan yang operasional dan mudah dipahami bagi pendidik, yang berisi berbagai contoh-contoh kegiatan pembelajaran yang sesuai dengan kurikulum. Penelitian ini bertujuan untuk mengembangkan buku panduan model pembelajaran yang menstimulasi keterampilan sosial bagi pendidik di Taman Kanak-kanak dengan berbagai contoh penerapannya di dalam aktivitas pembelajaran. Buku ini berisi daftar kegiatan fisik dari berbagai program kegiatan belajar yang mengembangkan keterampilan sosial.

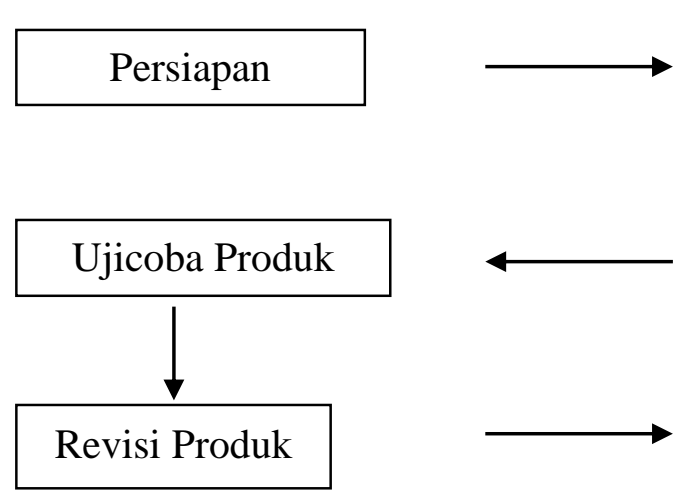

\section{METODE}

Penelitian ini merupakan penelitian pengembangan dengan menggunakan pendekatan kualitatif dengan didukung data kuantitatif. Model pengembangan yang digunakan dalam penelitian ini menggunakan model pengembangan Dick \& Carrey (Sanjaya, 2011:75). Model Pengembangan Dick \& Carrey, berorientasi pada tujuan pembelajaran. Prosedur pengembangan produk dilakukan melalui empat tahap: 1) tahap persiapan, 2) tahap pengembangan produk, 3) tahap ujicoba produk dan 4) tahap revisi.

Dari model pengembangan dibuat prosedur pengembangan baru. Prosedur yang direncanakan akan dilakukan dalam penelitian ini sebagaimana digambarkan pada skema 1.

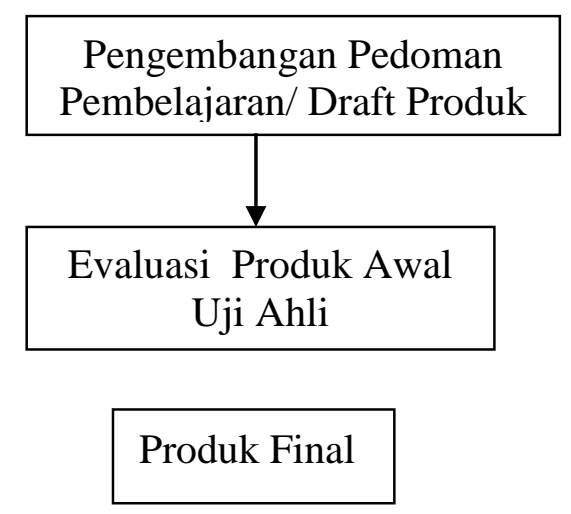

\section{Skema 1. Prosedur pengembangan modifikasi dari Dick \& Carrey}

Subyek penelitian ini adalah para pendidik TK di Kabupaten Sleman, Bantul, Gunung Kidul, Kulon Progo, dan Kotamadya Yogyakarta. Setiap kabupaten diwakili oleh 15 pendidik untuk menjadi subjek penelitian.

Pengumpulan data dilakukan secara kualitatif yang dilakukan dengan studi literatur dan Focus Group Discussion (FGD). FGD merupakan salah satu metode pengumpulan data dalam penelitian kualitatif (Gill, Stewart, Treasure \& Chadwick, 2008:294). FGD dilakukan dengan pendidik-pendidik TK untuk menggali model pembelajaran yang diaplikasikan dalam pembelajaran di TK.
Pengambilan data juga dilakukan dengan observasi terhadap keterampilan sosial anak TK. Observasi dilakukan sebelum dan setelah ujicoba model pembelajaran, serta pemberian angket pada pendidikpendidik TK untuk mengetahui penggunaan model pembelajaran yang dikembangkan setelah diterapkan dalam kegiatan pembelajaran di TK. Dalam penelitian ini pengumpulan data dilakukan dengan bantuan panduan FGD, panduan observasi berupa ceklis.

Data-data yang sudah terkumpul selanjutnya dianalisis secara deskriptif kuantitatif dan kualitatif. Data dari hasil FGD dianalisis secara kualitatif deskriptif, 
sedangkan data dari observasi melalui cheklist terkait keterampilan sosial anak TK dan perubahannya setelah mendapatkan pembelajaran yang menstimulasi keterampilan sosial dianalisis secara kuantitatif.

\section{HASIL DAN PEMBAHASAN}

Prosedur penelitian ini terdiri dari 5 langkah utama yaitu: Persiapan, pengembangan, pengembangan pedoman pembelajaran atau produk awal, ujicoba pedoman pembelajaran, evaluasi produk awal, implementasi produk akhir dan evaluasi akhir. Berikut ini deskripsi masing-masing langkah tersebut:

\section{Langkah 1: Persiapan}

Tahap persiapan dilakukan untuk mendapatkan informasi tentang sejauh mana pengembangan pedoman pembelajaran keterampilan sosial ini dibutuhkan. Data diambil dari hasil penelitian sebelumnya yang sudah dibuat oleh Yulia Ayriza dkk., dan dari hasil diskusi kelompok terarah (FGD) dengan pendidik-pendidik TK di Daerah Istimewa Yogyakarta dan angket yang peneliti berikan.

Data dari penelitian sebelumnya yang dilakukan Yulia, dkk menunjukkan bahwa pendidik-pendidik TK belum secara terprogram melakukan pembelajaran keterampilan sosial di sekolah dan dibutuhkan kesadaran untuk melakukannya di sekolah.

Pelaksanaan FGD dilakukan dengan melibatkan 49 pendidik-pendidik TK di DIY. Dari hasil diskusi kelompok terarah (FGD) dan angket menunjukkan bahwa hampir semua pendidik TK sudah memberikan contoh-contoh pembelajaran keterampilan berempati dalam kegiatan sehari-hari. Pembelajaran keterampilan sosial dilakukan baik secara terprogram maupun tidak terprogram. Namun kegiatan yang dilakukan secara tidak terprogram lebih banyak dilakukan. Pembelajaran yang dilakukan banyak yang sifatnya masih rutinitas dan tidak direncanakan dalam suatu perencanaan program pembelajaran yang matang. Bahkan, sebagian pendidik belum pernah membuat rencana atau skenario pembelajaran yang mengembangkan keterampilan berempati. Semua pendidik menyatakan membutuhkan contoh pembelajaran keterampilan sosial karena akan mempermudah pendidik dalam menanamkan keterampilan sosial pada anak dalam berbagai kegiatan pembelajaran di sekolah.

\section{Langkah 2 : Pengembangan Pedoman Pembelajaran.}

Beberapa langkah yang dilakukan dalam tahap ini adalah:

Menentukan karakteristik sasaran pengguna buku panduan ini, yaitu pendidik-pendidik atau pendidik TK yang berkewajiban untuk mendidik anak-anak TK baik secara kognitif, emosi dan sosial.

1. Standar kompetensi yang diharapkan muncul setelah mempelajari pedoman pembelajaran keterampilan sosial ini adalah Pendidik-pendidik TK mampu membuat program pembelajaran keterampilan sosial secara terstruktur dan terencana

2. Indikator kompetensi dasar pedoman pembelajaran keterampilan sosial ini yaitu:

a. Pendidik TK memahami arti penting dan landasan teoritik pembeljaran keterampilan sosial di TK

b. Pendidik dapat membuat rencana program pembelajaran keterampilan sosial

c. Pendidik dapat melaksanakan program pembelajaran yang dibuat dalam kegiatan pembelajaran di TK

d. Pendidik dapat melakukan evaluasi kegiatan pembelajaran yang sudah dilakukan

3. Mengembangkan materi pembelajaran, meliputi:

a. Bagian pertama, Pendahuluan: Arti penting Pembelajaran Keterampilan Sosial pada Anak TK, untuk siapa buku digunakan 
dan bagaimana menggunakan buku panduan ini.

b. Bagian kedua, Landasan Teoritis: Keterampilan Sosial pada Anak Prasekolah, Konsep

Pembelajaran yang menjadi Acuan.

c. Bagian ketiga yang menjelaskan: Berbagai Aspek Keterampilan Sosial Anak dan Contoh-contoh Program Pembelajaran baik yang terkait dengan pengembangan kebiasaan positif.

4. Mengembangkan skenario pembelajaran yang meliputi : topik, sub topik, indikator, materi, metode, media, skenario pembelajara dan alokasi waktu dan perencanaan format evaluasi. Ada tiga aspek keterampilan sosial sebagaimna dijelaskan sebelumnya, masing-masing aspek dikembangkan 5 macam skenario pembelajaran

\section{Langkah (3) : Evaluasi Produk Awal}

Pada langkah ini yaitu dilakukan review produk awal dengan meminta masukan pada dua orang ahli media pembelajaran yang juga memahami pendidikan anak usia dini. Reviewer produk penelitian ini adalah Dr. Haryanto dan Dr. Ch. Ismaniati yang merupakan dosen Jurusan KTP FIP UNY. Data reviewer baik dari kedua ahli tersebut digunakan untuk mengetahui kelayakan produk awal dan sebagai masukan untuk mengembangan produk berikutnya.

Hasil penilaian dari reviewer terkait dengan kualitas aspek pembelajaran, materi pembelajaran, dan aspek tampilan pedoman pembelajaran keterampilan sosial yang dibuat peneliti menunjukkan skor 4 (baik) dan 5 (sangat baik). Hasil tersebut menunjukkan buku pedoman pembelajaran yang peneliti buat bagus dan layak untuk diproduksi. Meskipun demikian ada beberapa masukan dari reviewer untuk perbaikan produk yang sudah dihasilkan, diantaranya: Daftar Isi belum ada, Penulisan tanda baca, kata dan kalimat masih banyak yang belum baku, adanya bias gender pada gambar pendidik yang semuanya berjenis kelamin perempuan, Kompetensi dan indikator pembelajaran yang dikembangkan pada buku panduan ini masih tersurat dan perlu dipertegas, dalam skenario pembelajaran yang dibuat masih berpusat pada pendidik, dan beberapa belum menjelaskan evaluasinya. Beberapa perbaikan yang dilakukan dapat dilihat dalam Tabel 1.

\section{Tabel 1. Bagian Buku Pedoman yang Sebelum dan Setelah diperbaiki (Hasil Evaluasi Produk Awal)}

\begin{tabular}{|c|c|c|}
\hline Bagian Buku Pedoman & Sebelum diperbaiki & Setelah diperbaiki \\
\hline Daftar Isi & Belum ada & Ada di halaman $\mathrm{v}$ \\
\hline Kompetensi dan indikator & $\begin{array}{lr}\text { Pada } & \text { bagian } \\
\text { pendahuluan } & \text { masih } \\
\text { tersirat } & \end{array}$ & $\begin{array}{l}\text { Dituliskan lebih detail } \\
\text { pada halaman } 2 \text { dan } 3\end{array}$ \\
\hline $\begin{array}{l}\text { Gambar pada skenario } \\
\text { pembelajaran }\end{array}$ & $\begin{array}{l}\text { Gambar pendidik } \\
\text { semuanya wanita, ada } \\
\text { bias gender }\end{array}$ & $\begin{array}{l}\text { Ada gambar pendidik } \\
\text { laki-laki pada halaman } \\
34\end{array}$ \\
\hline Skenario pembelajaran & $\begin{array}{l}\text { Beberapa masih belum } \\
\text { dituliskan evaluasi } \\
\text { pembelajaran }\end{array}$ & $\begin{array}{l}\text { Evaluasi yang belum ada } \\
\text { sudah ditambahkan, } \\
\text { dapat dilihat halaman }\end{array}$ \\
\hline Salah ketik & $\begin{array}{l}\text { Beberapa penulisan } \\
\text { salah ketik }\end{array}$ & Perbaikan salah ketik \\
\hline
\end{tabular}




\section{Langkah 4: Ujicoba Produk}

Uji Coba dilakukan dengan melibatkan 31 pendidik TK yang berasal dari beberapa sekolah di DIY. Pendidikpendidik tersebut diminta untuk memahami buku panduan keterampilan sosial (produk yang sudah dibuat) dan mencoba menerapkan pembelajaran keterampilan sosial di sekolah masingmasing sesuai dengan buku panduan yang sudah dibaca selama 2 minggu, sejak tanggal 28 Oktober 2009 hingga 11 Nopember 2009. Para pendidik TK tersebut, selanjutnya melakukan evaluasi dan penguatan secara bergantian. Setelah pembelajaran keterampilan sosial diberikan sesuai dengan skenario yang sudah ada, pendidik-pendidik TK diminta melakukan observasi perilaku sosial anak setelah mendapatkan pembelajaran keterampilan sosial.

\section{Langkah 5: Evaluasi Produk}

Setelah produk diujicoba, pendidikpendidik diminta memberi masukan terkait dengan hasil ujicobanya. Berdasar angket yang sudah diisi pendidik menunjukkan kualitas aspek pembelajaran yang terdapat dalam pedoman pembelajaran keterampilan sosial dengan skor rata-rata 3,62 pada aspek pembelajaran, skor ratarata 3,34 pada aspek tampilan, dan skor rata-rata 3,51 pada aspek materi pembelajaran. Hasil tersebut menunjukkan bahwa secara keseluruhan pedoman pembelajaran keterampilan sosial yang dibuat peneliti adalah cukup baik dari aspek pembelajaran, tampilan, maupun materinya. Hasil evaluasi, tampilan, maupun materinya secara lebih mendetail dapat dilihat pada Tabel 2.

Berdasarkan data pada angket terbuka, ada beberapa saran dari pendidik untuk memperbaiki buku pedoman ini diantaranya:

1. Gambar sebaiknya berwarna seperti cover.

2. Contoh pembelajaran atau skenario dibuat lebih banyak dan lebih variatif dan dibuat lebih sederhana.
3. Ditekankan agar pendidik selalu mengingatkan anak dan diulangulang.

4. Dilengkapi buku/alat peraga berwarna untuk anak.

5. Gambar sebaiknya yang asli; skenario sebaiknya jadi satu halaman.

Dari hasil diskusi kelompok terarah (FGD) pada pendidik-pendidik yang telah menerapkan pembelajaran keterampilan sosial memberi masukan lebih detail pada beberapa bagian dari buku pedoman tersebut, yaitu:

1. Gambar cover pada halaman depan terkesan kegiatan gotong royong dan kurang menggambarkan keseluruhan keterampilan sosial anak, sehingga perlu untuk ditambah kegiatan anak yang lain misalnya ada anak sedang menolong temannya, ada anak lain yang sedang bersalaman, atau meminjam barang teman.

2. Dalam bagian penggunaan buku, perlu dituliskan secara jelas kapan menerapkan pembelajaran keterampilan sosial dan bagaimana penerapannya.

3. Hurufnya kurang besar dan kurang seimbang dengan besarnya ukuran buku.

4. Bahasan pada materi afiliasi dan resolusi masih ada beberapa istilah yang sulit dipahami.

5. Gambar-gambar pada skenario pembelajaran lebih baik dibuat warna.

6. Penulisan lagu pada buku pedoman perlu disertai not baloknya atau diberi penjelasan bisa diganti dengan lagu yang sejenis.

7. Beberapa gambar perlu dibuat lebih detail, seperti gambar rumput yang terkesan seperti semut, jika gambarnya tidak berwarna, gambar pembiasaan gosok gigi yang kurang disertai dengan peralatan yang disediakan dan latar belakang gambar. 
8. Letak gambar dan skenario perlu

konsisten dan perlu diberi judul.

Tabel 2. Kesimpulan Masukan dan Perbaikan Buku Pedoman

\begin{tabular}{|c|c|c|}
\hline Aspek & Masukan & Perbaikan \\
\hline a. Cover & $\begin{array}{l}\text { Gambar menunjukkan isi buku secara } \\
\text { keseluruhan }\end{array}$ & Perbaikan Gambar \\
\hline b. Huruf & Diperbesar (sebelumnya ukuran 11) & Huruf diperbesar menjadi 12 \\
\hline c. Tata letak & Gambar dan skenario bersisian & Perbaikan tata letak \\
\hline \multirow[t]{3}{*}{ d. Gambar } & $\begin{array}{l}\text { Jumlah anak ditambah dan balok diganti } \\
\text { bentuk-bentuk geometri }\end{array}$ & Perbaikan Gambar \\
\hline & Rumput seperti semut & Perbaikan Gambar \\
\hline & $\begin{array}{l}\text { Menggosok gigi di luar kelas dan anak } \\
\text { memegang cangkir }\end{array}$ & Perbaikan Gambar \\
\hline a. Istilah & Afiliasi dan resolusi konflik & $\begin{array}{l}\text { a. Afiliasi adalah hal yang } \\
\text { berkaitan dengan pertalian } \\
\text { atau hubungan dengan } \\
\text { orang lain. Hal ini } \\
\text { menunjukkan kemampuan } \\
\text { untuk mengidentifikasi } \\
\text { perilaku yang dapat } \\
\text { diterima secara sosial } \\
\text { b. Resolusi Konflik adalah } \\
\text { bagian dari keterampilan } \\
\text { sosial yang berfungsi untuk } \\
\text { menyelesaikan konflik atau } \\
\text { masalah }\end{array}$ \\
\hline $\begin{array}{l}\text { a. Petunjuk } \\
\text { penggunaan }\end{array}$ & $\begin{array}{l}\text { Belum jelas kapan dan bagaimana } \\
\text { digunakan }\end{array}$ & $\begin{array}{l}\text { Program pembelajaran ini } \\
\text { diintegrasikan dengan standar } \\
\text { kurikulum yang dipakai dan } \\
\text { hendaknya digunakan terus } \\
\text { menerus }\end{array}$ \\
\hline $\begin{array}{l}\text { b. Kesalahan } \\
\text { ketik }\end{array}$ & Buang bukan senang & Diganti dengan kata buang \\
\hline
\end{tabular}

Keterampilan Sosial Anak TK setelah
Mendapatkan
Peterampilan Sosial
$\quad$ Pembelajaran keterampilan sosial idealnya akan menstimulasi keterampilan sosial anak. Dalam penelitian ini pendidikpendidik mengajarkan keterampilan sosial pada anak dan diminta untuk melakukan observasi perilaku anak yang mencerminkan keterampilan sosialnya dalam keseharian di kelas. Observasi dilakukan sebelum dan setelah pembelajaran keterampilan sosial diberikan pendidik. Ada 138 anak ikut berpartisipasi di dalamnya. Hasilnya menunjukkan rata-rata skor keterampilan sosial anak mengalami peningkatan setelah mendapat pembelajaran keterampilan sosial, baik pada aspek empati, afiliasi dan resolusi konflik maupun pengembangan kebiasaan positif. Rata-rata skor sebelum dan sesudah pembelajaran secara lebih mendetail dapat dilihat pada tabel 3 . 
Tabel 3. Hasil Uji Peningkatan Keterampilan Sosial

\begin{tabular}{llr}
\hline Komponen Keterampilan Sosial & & Mean \\
\hline \multirow{2}{*}{ Empati } & Sebelum observasi & 11,9571 \\
& Setelah observasi & 14,5429 \\
Afiliasi dan resolusi konflik & Sebelum observasi & 12,8718 \\
& Setelah observasi & 16,8718 \\
Pengembangan kebiasaan positif & Sebelum observasi & 9,6897 \\
& Setelah observasi & 17,2759 \\
\multirow{2}{*}{ Keseluruhan } & Sebelum observasi & 34,2414 \\
& Setelah observasi & 47,8966 \\
\hline
\end{tabular}

Tabel 4. Hasil uji beda sebelum dan setelah observasi

\begin{tabular}{lllll}
\hline & & & & \\
& & $\mathrm{t}$ & $\mathrm{df}$ & Sig. (2-tailed) \\
\hline Empati & pre1 - post1 & $-4,794$ & 69 & 0,000 \\
$\begin{array}{l}\text { Afiliasi dan resolusi } \\
\text { konflik }\end{array}$ & pre2 - post2 & $-5,507$ & 38 & 0,000 \\
$\begin{array}{l}\text { Pengembangan } \\
\text { Kebiasaan Positif }\end{array}$ & pre3 - post3 & $-7,628$ & 28 & 0,000 \\
Keseluruhan & pretot - posttot & $-15,696$ & 28 & 0,000 \\
\hline
\end{tabular}

Hasil pada tabel 3 di atas menunjukkan ada peningkatan rata-rata skor keterampilan sosial pada ketiga aspek keterampilan sosial. Hasil tersebut menunjukkan keterampilan sosial anak meningkat, setelah mendapatkan pembelajaran keterampilan sosial dengan menggunakan buku pedoman yang penulis buat. Selanjutnya dianalisis secara inferensi. Dengan menggunakan analisis uji $t$, didapatkan hasil sebagaimana ditunjukkan pada tabel 4. Berdasar tabel tersebut didapatkan hasil signifikansi $\mathrm{p}<$ 0,05 pada hasil uji beda sebelum dan sesudah observasi pada ketiga aspek maupun secara keseluruhan dan keseluruhan. Hasil tersebut menunjukkan ada perbedaan aspek empati, afiliasi dan resolusi konflk dan pengembangan kebiasaan positif sebelum dan setelah pembelajaran. Dengan demikian dapat disimpulkan bahwa penggunaaan buku panduan ini dapat meningkatkan keterampilan sosial anak TK secara signifikan, artinya adanya peningkatan keterampilan sosial setelah pembelajaran dengan menggunakan buku pedoman yang sudah peneliti buat juga dapat diaplikasikan pada pendidik TK yang lainnya, selama memiliki karakteristik yang sama dengan subjek peneliti.

\section{PENUTUP}

Berdasar hasil penelitian ini, peneliti telah berhasil menyusun pedoman pembelajaran keterampilan sosial. Pedoman pembelajaran dibuat melalui uji ahli dan ujicoba di lapangan. Hasil evaluasi ahli menunjukkan pedoman pembelajaran keterampilan sosial ini layak untuk diproduksi dengan beberapa saran perbaikan. Setelah diperbaiki, buku pedoman pembelajaran diujicobakan di lapangan. Hasil penilaian pendidik TK menunjukkan buku pedoman pembelajaran keterampilan sosial ini secara keseluruhan 
cukup baik, dan setelah diujicobakn pada pembelajaran di TK menunjukan bahwa pembelajaran keterampilan sosial dapat meningkatkan rata-rata skor keterampilan sosial pada ketiga aspek keterampilan sosial.

\section{DAFTAR PUSTAKA}

Asendorpf, J.B., Denissen, J.J.A., \& van Aken, M.A.G. (2008). Inhibited and agressive preschool children at 23 years of age: Personality and social transitions into adulthood. Developmental Psychology, 44, 9971011.

Ayriza, Y., Izzaty, R.E., \& Setiawati, F.A. (2004-2006). Pengembangan Modul Sosial Skill untuk Anak-anak Prasekolah dan Model Sosialisasinya. Yogyakarta: Pusdi PAUD.

Brewer, J.A. (2007). Introduction to Early Childhood Education. Boston: Allyn $\&$ Bacon.

Cartledge, G. \& Milburn, J.F. (1995). Teaching Social Skills to Children and Youth: Innovative Approaches $\left(3^{\text {rd }}\right.$ ed). Boston: Allyn and Bacon.

Curtis, A. (1988). A Curriculum for the Pre-school Child. New York: Routledge.

Gill, P., Stewart, K., Treasure, E., \& Chadwick, B. (2008). Methods of data collection in qualitative research: interviews and focus groups. British Dental Journal 204, 291-295.

Izzaty, R.E. (2008). Berbagai Strategi Pemecahan Masalah Sosial Anak TK. Pra-survey.

$$
\text { (2005). Prediktor }
$$

Permasalahan Tingkah Laku Anak

Usia TK. Tesis. Yogyakarta: Universitas Gadjah Mada.

(2004).

Mengenali

Permasalahan Perkembangan Anak Usia TK: Buku Ajar Bidang PGTK. Jakarta: Direktorat Jenderal Pendidikan Tinggi.

Lawhon, T., \& Lawhon, D.C. (2000). Promoting social skill in young children. Early Childhood Education Journal, Vol. 28, No. 2.

Mayeux, L., \& Cillessen, A.H.N. (2003). Development of social problem solving in early childhood. The Journal of Genetic Psychology, 162 (2), 153-173.

Ramdhani, N. (1991). Standardisasi skala tingkah laku sosial. Laporan Penelitian.. Yogyakarta: Fakultas Psikologi UGM.

Sanjaya, W. (2011). Perencanaan dan Desain Sistem Pembelajaran. Jakarta: Kencana Prenada Media Group.

Stormshak, E.A., \& Welsh, J.A. (2005). Social competence: A developmental framework. In Teti, D. M. I. Handbook of Research Methods in Developmental Science. Australia: Blackwell Publishing. 